\title{
THE IMPLEMENTATION OF COLLABORATIVE STRATEGY READING (CSR) AND ITS EFFECTS ON STUDENTS' READING COMPREHENSION
}

\author{
Indah Fadhilah Rahman \\ English Education Department of UIN Alauddin Makassar \\ fadhilah_iin30@yahoo.co.id
}

\begin{abstract}
This research aimed to find out: (1) the students' attitude toward CSR in teaching-reading comprehension and (2) the role of CSR and its affects on students' reading comprehension. This study was experimental which involved two groups: experimental and control groups. The research was conducted at Madrasah Aliyah Negeri MAN 1 Makassar, South Sulawesi with 40 students as respondents. The instruments of data collection were pre-test, treatment, post-test, and questionnaire. The reading test was administered to both groups. The scores were assessed by two assessors. The data were analyzed and interpreted by means of SPSS 14.0. The study reveals that the implementation of CSR has a significant effect on students' reading proficiency in terms of content of the text: preview, clik and clunk, get the gist and wrap up. The results of students' reading score from pre-test to post-test demonstrate a significant difference. It is found that sig. (2tailed) is 0.000 lower than 0.05 . The comparison of the students' reading proficiency outcome between the two groups $(8.592>2.024)$ shows that the improvement is significant. The finding signifies that CSR is positively responded by the experimental class. The implementation of CSR increases students' reading proficiency.
\end{abstract}

KEY WORDS: Collaborative Strategy Reading, Reading Comprehension, And Students' Attitude

\section{A. INTRODUCTION}

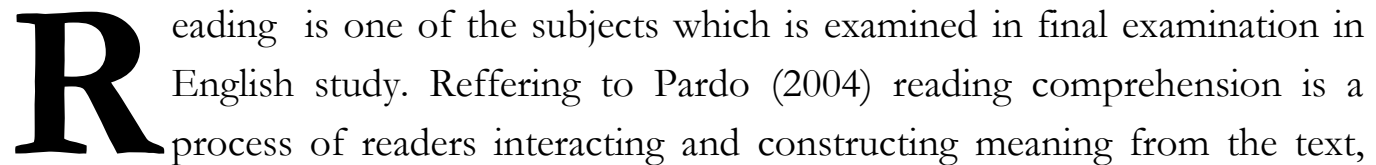

implementing the use of prior knowledge, and the information found in the text. As we know that "the more we read, the more we know" Vos in Dryden, G. et al (1999). Tthrough this statement, we realize how important reading in increasing our mind and perspective. We can say that reading is a key to get information. Teaching and learning reading comprehension is not necessary if we know the way or technique how to comprehend the reading text. There are many strategies and methods which 
Indah Fadhilah Rahman, The Implementation of Collaborative Strategy Reading (CSR) ...

can be used in teaching reading comprehension. The reality of the teaching and learning reading comprehension in Madrasah Aliyah Negeri MAN 1 Makassar reveals that students have problems and tend to find many difficulties in reading comprehension. So far, based on the researcher's preliminary research by interview with the teachers and students in this collage, there are number of crucial issues concerning the teaching and learning of reading comprehension. First of all, some students always feel bored when they are studying reading because they do not know the technique to understand the reading material easily and they lack vocabulary. Secondly, students' poor knowledge becomes one cause that makes them difficult to comprehend the reading text. Next, the students' condition during learning process is low motivation and uninteresting in content of material. So, the researcher is interested in presenting the collaborative strategy reading in teaching them. As we know that the Collaborative Strategy Reading (CSR) is cooperative learning strategy that can help the students to solve their problem in reading comprehension. In this learning strategy, students will study by small group.

CSR) was developed by Janette K, Klingner and Sharon Vaughn in 1996 and 1998. CSR is a reading comprehension technique that combines two instructional elements: (1) modified reciprocal teaching (Palincsar \& Brown, 1984) and (2) cooperative learning or students pairing (Johnson \& Johnson, 1987). In reciprocal teaching, teacher and students take turns leading a dialogue concerning key feature of the text through summarizing, questioning, clarifying and predicting, and in cooperative learning, the students brainstorming, predict, clarify words and phrases, highlight the main idea, summarize the main idea(s) and important detail and ask and answer questions.

Concerning CSR used by students who learn English (Janette, et al.1996 and 1998), in her study, suggests the four strategies in teaching reading comprehension: preview (brainstorming or prior knowledge), click and clunk (identify the difficulty and understanding material), get the gist (find out or identify the main idea(s) and information(s) and wrap up (ask and answer questions) the story from English text books that they read (Janette et al., 1996 and 1998). The four strategies are related to students' interaction with other people as the effect of CLT movement in English language teaching.

Thus, CLT movement has brought social interaction to an important position that, as a core of communication, it plays significant role in language learning. Referring to Brown (2001), interaction is the heart of communication where everything about communication happens in interaction, moreover, Oxford suggests that involvement other people in the process of learning a language is very important 
because language is communication (Oxford, 1990). Bandura agrees with the concept regarding the role of interaction in learning process by saying that people cannot achieve their accomplishment on their own ability, they need others' help (Bandura, 2001). The role of social interaction in language learning is actually an important element of constructing knowledge and understanding of the target language (Tobias et al., 2009, Suryabrata, 2011).

In this case, a study which is intended to enhance students' motivation and improve their students' proficiency in reading comprehension is considered necessary. CSR strategy can be considered as a strategy that can solve the problems above. The researcher chose CSR because CSR is still controversial issue. It can be seen from the previous studies that many researchers have investigated on CSR. It has a positive response on the use of CSR in reading classroom because it can improve students' students' proficiency.

\section{B. LITERATURE REVIEW}

Learning is the process of acquiring knowledge, skills, attitudes, or values through study experience, or teaching, that cause a change of behavior that is persistent measurable, and specified or allow an individual to formulate a new mental construct or revise a prior mental. Joice, B., \& Weil (1984:2) declare that the result of each learning experience is not only the content, but also the greater ability of acquiring future learning task. The results of learning involve information, ideas, skills, values, ways of thinking, means of expression, and learn how to learn.

\section{Collaborative Strategy Reading (CSR)}

CSR is the combination of two methods, namely, teaching the reciprocal strategy and cooperative learning group activity or student pairing. CSR is designed for students who have very low comprehension in reading English text. This strategy is used to promote content learning, language acquisition, and reading comprehension in English classrooms (Klingner et al., 1998).

According to Lucille Sullivan (1968) in Janned et al (1998: 32):

"Collaborative Strategy Reading (CSR) is an excellent technique for teaching students reading comprehension and building vocabulary and also working together cooperatively".

Sallie Gotch (1961) in Janned et al (1998: 36) says that:

Special Education Inclusion Teacher statement CSR is great for kids with learning disabilities because they contribute to their groups and feel successfull, and they get the help they need with their reading. 
Indah Fadhilah Rahman, The Implementation of Collaborative Strategy Reading (CSR) ...

In CSR, students learn four tecniques: preview, click and clunk, get the gist, and wrap up. Preview is used before reading the entire text for the lesson, and wrap up is used after reading the entire text for the lesson. The other two strategies click and clunk and get the gist are used multiple times while reading the text in each paragraph.

Preview is a strategy used to activate students' prior knowledge in order to facilitate their predictions about what they will read, and to generate interest. A teacher introduces previewing to students by asking them to think about the previews they have seen at the movies or reading text. The teacher prompts students to tell what they learn from previews by asking questions such as, "do you learn who is going to be in the movie?" or "do you learn in what historical period the movie will take place?". The teacher then asks them to skim information such as headings, pictures, and words that are bolded or underlined to determine (a) what they know about the topic and (b) what they think they will learn by reading the text.

Click and clunk is a strategy that teaches students to monitor their understanding during reading, and to use fix-up strategies when they realize their failure to understand text. The teacher describes a click as something that "you really get. You know it just clicks." After students understand, the teacher explains "A clunk is like when you run into a brick wall. You just really don't understand a word the author is using. That's a clunk." Then, the teacher reads a short piece aloud and asks students to listen carefully for clunks. The teacher asks students to write down their clunks and then teaches fix-up strategies to figure out the clunks. The teacher can use "clunk cards" as reminders of fix-up strategies.

Get the gist is a strategy to help students identify main ideas during reading. One way to identify the main idea is to answer the following questions: (a) "who or what is it about?" and (b) "what is most important about the "who or what?" In addition, students are taught to limit their response to ten words or less, so their gist conveys the most important idea(s), but not unnecessary details. Get the gist can be taught by focusing on one paragraph at a time. While students read the paragraph, the teacher asks them to identify the most important person, place, or thing. Then, the teacher asks students to tell what is the most important about the person, place, or thing. Finally, the teacher teaches students to put it all together in a sentence containing ten words or less.

Wrap up is a strategy that teaches students to generate questions and to review important ideas in the text they have read. The teacher initially teaches students to wrap up by telling students to pretend they are teachers and to think of questions they would ask on a test. The teacher suggests the following question 
starters: who, what, when, where, why, and how. The teacher also encourages students to generate some questions that require an answer involving higher-lever thinking skills, rather than literal recall. Finally, the teacher asks students to write down the most important ideas from the day's reading assignment.

The students are able to apply CSR's reading comprehension strategies and help each other while working in their cooperative groups, the teacher's role is to circulate among groups and provide ongoing assistance. Teachers help by actively listening to students' discussions and providing feedback, clarifying difficult words, modeling strategy usage, encouraging students to participate, and providing positive reinforcement. The focus of students' work should be on learning the material and helping their classmates learn it as well, not merely going through the steps of a given strategy. Also, teachers should regularly conduct whole-class previews and wrap ups to introduce new material, facilitate follow up activities, and reinforce learning.

\section{Materials for CSR}

The following materials may be helpful as we assist students to use both cooperative learning techniques and comprehension strategies. Cue cards or sheets can be effective reminders of cooperative learning roles.

Cue cards outline the procedures to be followed in cooperative learning groups and provide structure and support for students while they are learning CSR. Each role comes with a corresponding cue sheet that explains the steps to be followed to fulfill that role. Cue sheets seem to help students stay focused and on task, and increase their confidence. Students should discontinue use of the cue sheets when they feel secure in carrying out their roles.

CSR learning logs enable students to keep track of learning "as it happens" and provide a springboard for follow-up activities. Logs furnish an additional way for all students to participate actively in their groups. Logs can be used for recording ideas while applying every strategy, or only used for some of the strategies (e.g., for writing down clunks and key ideas).

Reading materials in CSR was designed primarily to be used with expository text found in social studies and other content area textbooks, yet CSR can also be used with narrative text. You should select reading material with well-formed, interesting passages that are conducive to strategy application. Such material is characterized by some steps which are providing clues that help students predict what they will be learning, having one main idea in a paragraph, and providing context that helps students connect information. 
Indah Fadhilah Rahman, The Implementation of Collaborative Strategy Reading (CSR) ...

Time. A timer is optional. Kitchen timers that students set by themselves can help groups to remain on task and not get excessively bogged down with any one strategy or step in the CSR process. For example, the timekeeper might say, "We have 10 minutes to write down everything we already know about the topic." Then the timekeeper would set the timer for 10 minutes. An alternative is for the teacher to set one timer and direct students in their groups to carry out the strategies for a set period of time.

\section{The Students' roles}

Students' roles are an important aspect of CSR because cooperative learning seems to work best when all group members have been assigned a meaningful task. Roles should rotate on a regular basis so that students can experience a variety of roles and so that everyone takes a turn being the Leader. Students can perform more than one role at a time, if necessary. Possible roles include the following: (1). Leader, Student leads the group in the implementation of CSR by saying what to read next and what strategy to apply next. The leader asks the teacher for assistance, if necessary. (2). Clunk expert, Student uses clunk cards to remind the group of the steps to follow when trying to figure out a difficult word or concept. (3). Announcer, Student calls on different group members to read or share an idea. He or she makes sure everyone participates and only one person talks at a time, (4). Encourager, Student watches the group and gives feedback. He or she looks for behaviors to praise. The student encourages all group members to participate in the discussion and assist one another. He or she evaluates how well the group has worked together and gives suggestions for improvement. (5). Reporter, During the whole-class wrap-up, the student reports to the class the main ideas the group learned and shares a favorite question the group has generated and (6). Time keeper. Student sets the timer for each portion of CSR and lets the group know when it is time to move on (the teacher might do this instead of students).

\section{The Teachers' roles}

Tearcher can help by actively listening to students' conversations and if necessary clarifying difficult words, modeling strategy usage, encouraging students to participate, and modeling a helpful attitude. It is expected that students will need assistance learning to work in cooperative groups, implementing the strategies, and mastering academic content. 
Volume I, Number 01, June 2015

\section{Reciprocal Strategy}

Reciprocal teaching is a strategy to teach reading where the teacher and the students share responsibility for interpreting the material. The students and the teacher go through four steps of summarizing, question generating, clarifying and predicting. Reciprocal teaching is a research-based strategy with a growing body of studies cementing its foundation. Addition Palincsar (1986) states the purpose of reciprocal teaching is to facilitate a group effort between teacher and students as well as among students in the task of bringing meaning to the text.

Summarizing provides the opportunity to identify and integrate the most important information in the text. Text can be summarized across sentences, across paragraphs, and across the passage as a whole. When the students first begin the reciprocal teaching procedure, their efforts are generally focused at the sentence and paragraph levels. As they become more proficient, they are able to integrate at the paragraph and passage levels.

Question generating reinforces the summarizing strategy and carries the learner one more step along in the comprehension activity. When students generate questions, they first identify the kind of information that is significant enough to provide the substance for a question. They then pose this information in question form and self-test to ascertain that they can indeed answer their own question. Question generating is a flexible strategy to the extent that students can be taught and encouraged to generate questions at many levels. For example, some school situations require that students master supporting detail information; others require that the students be able to infer or apply new information from text.

Clarifying is an activity that is particularly important when working with students who have a history of comprehension difficulty. These students may believe that the purpose of reading is saying the words correctly; they may not be particularly uncomfortable that the words, and in fact the passage, are not making sense. When the students are asked to clarify, their attention is called to the fact that there may be many reasons why text is difficult to understand (e.g., new vocabulary, unclear reference words, and unfamiliar and perhaps difficult concepts). They are taught to be alert to the effects of such impediments to comprehension and to take the necessary measures to restore meaning (e.g., reread, ask for help).

Predicting occurs when students hypothesize what the author will discuss next in the text. In order to do this successfully, students must activate the relevant background knowledge that they already possess regarding the topic. The students have a purpose for reading: to confirm or disprove their hypotheses. Furthermore, the opportunity has been created for the students to link the new knowledge they will 
Indah Fadhilah Rahman, The Implementation of Collaborative Strategy Reading (CSR) ...

encounter in the text with the knowledge they already possess. The predicting strategy also facilitates use of text structure as students learn that headings, subheadings, and questions imbedded in the text are useful means of anticipating what might occur next.

\section{Cooperative Learning Definitions}

There are many definitions of cooperative learning from many experts. Roger (1992:22) states that cooperative learning is a group learning activity organized in such a way that learning is based on the socially structured change information between learners in group in which each learner is held accountable for his or her own learning and is motivated to increase the learning of others. Parker (1994:27) defines cooperative learning as a learning condition in which learner makes interaction in small group to do the academic task in order to reach the same purpose. Meanwhile Davidson (1995:363) says cooperative learning means to work or to act together or jointly, and strive to produce an effect.

Moreover, Johnson and Johnson (1998:43) cooperative is working together to accomplish shared goals. Within cooperative activities individual seek outcomes that are beneficial to themselves and beneficial to all other group members. Cooperative is the instructional use of small group so that the students work together to maximize their own and each other's learning. It means that in cooperative situation, each member makes effort to reach the same goals. Newman (1987:21) add cooperative as small group of learners working together as a team to solve a problem, complete task, or accomplish common goal. In Jacob's opinion (1997:45) Cooperative learning is organised and managed group work in which students work cooperatively in small groups to achieve academic as well as affective and social goals. Other definition is a successful teaching strategy in which small teams, each with students of different levels of ability, use a variety of learning activities to improve their understanding of a subject. Each member of a team is responsible not only for learning what is taught but also for helping teammates learn, thus creating an atmosphere of achievement.

Based on the definitions above, it can be concluded that cooperative learning is a learning method in which learners are divided into a small group to help each other in to reach successful academic purpose. Johnson et al., (1991:2) elaborate five components of Cooperative Learning as follows:

\section{a. Positive interdependence.}

Students perceive that they need each other in order to complete the group's task ("sink or swim together"). Teacher may structure positive interdependence by establishing mutual goal (learn and make sure all other group members learn), 
joint rewards (if all group member achieve above the criteria, each will receive bonus point), shared resources (one paper for each group or each member receiver part of the required information), and assigned role (summarizer, encourager of participation, elaborator).

\section{b. Face-to-face promotive interaction}

Students promote each other's learning by helping, sharing, and encouraging efforts to learn. Students explain, discuss, and teach what they know to their classmates. Teachers structure the group so that student sit knee-to-knee and talk through each aspect of the assignment.

\section{c. Individual accountability}

Each the students' performance is frequently assessed and the results are given to the group and individual. Teachers may structure individual accountability by giving an individual test to each student or randomly selecting one group member to give the answer.

\section{d. Interpersonal and small group skill}

Group cannot function effectively if students do not have and use the needed social skills. Teachers teach these skills as purposefully and precisely as academic skills. Collaborative skills include leadership, decision-making, trust-building, communication, and conflict-management skills.

\section{e. Group processing}

Group needs specific time to discuss how well they are achieving their goal and maintaining effective working relationship among members. Teachers structure group processing by assigning such as (a) list at least the three member actions that helped the group be successful and (b) list one action that could be added to make the group even more successful tomorrow. Teachers also monitor the groups and give feedback on how well the groups are working together to the groups.

\section{The Advantages of Cooperative Learning}

Cooperative learning is extremely beneficial. There are some advantages of cooperative learning strategy in the teaching and learning process. According to Sharan (1990:18) cooperation can develop students' higher thinking skills. In this activity, students learn to evaluate, analyze, and synthesize the information that they need to learn. They improve their reasoning and logic skills. Slavin (1995: 66) says cooperative learning develops students' individual responsibility. In this activity, each individual has specific responsibilities. They learn that they need to fulfill those 
Indah Fadhilah Rahman, The Implementation of Collaborative Strategy Reading (CSR) ...

responsibilities because the other students are depending on them. The success of the group depends on each group member. Nobody can be a person who sits in the back of the room trying to be unnoticed.

Moreover, Johnson \& Johnson (1991:61), in traditional educational setting, students tend to work either on their own or in competition with one another. In a cooperative, group-oriented setting, all class members, particularly those grouped in instructor-selected teams, contribute to each other's learning. Through careful planning, positive interdependence can be established by having students achieve: (a) mutual goals, such as reaching a consensus on specific solutions to problems or arriving at team-generated solutions; (b) mutual rewards, such as individually assigned points counting toward a criterion-referenced final grade, points which only help, but never handicap; (c) structured tasks, such as a report or complex problem with sections contributed by each team member; and (d) interdependent roles, such as having group members serve as discussion leaders, organizers, recorders, and spokesperson.

According Tang (1998) In Barbara J. Mills, US Academy Force, co-operative learning provides a non-threatening learning context for interaction between students. During co-operative learning, students are exposed to other perspectives and alternatives, they share and exchange ideas, criticize and provide feedback. Peer feedback can help students increase their awareness of their learning aims, and of the strategies to employ to achieve those aims.

In addition, through cooperative learning activities, students learn how to see things from other people's point of view. They have to listen to what others think and seriously think about and evaluate what was said. They also develop empathy for others. They look at how decisions affect people in their group and determine whether or not it was good. Furthermore, Students develop self-confidence and self esteem. As they work on and solve difficult problems, they feel a sense of accomplishment. They realize that they can be successful. They can do the work and remember the material. Along with building self-confidence, cooperative learning builds social skills. Students learn how to get along, how to take turns, how to listen politely, and how to speak politely. Also, class attendance improves. When students realize that their group is depending on them, students don't skip school. They make sure that they go to class so they can work with their team.

\section{Disadvantages of Cooperative Learning}

While cooperative learning has many advantages, one of its biggest disadvantages is that grouping students together will almost always form a group in which some students are faster learners or workers than others. The students who 
need more time to understand the work may feel frustrated at being left behind. Alternately, students who learn faster may feel delayed or held back by having to wait for the ones that learn more slowly.

Another disadvantage of cooperative learning is that there are certain groups dynamics present in all groups. Some students will always be leaders while others are followers. If one student tries to take over the group and the other students don't feel equally heard or valued, it can make it difficult for work to be done. Instead, the students spend time arguing over who is in charge as opposed to working together toward a common goal (Curran, 1994: 122).

Moreover, cooperative learning may make the quiet students feel uncomfortable. More quiet students may not feel comfortable expressing themselves and their ideas with a group. The quiet students that never talk might still not feel comfortable talking to a group. In this case they are more comfortable talking to oneto-one. It can be said that this could still be a good thing because the person that is afraid to talk will have more of a chance to talk in the group. Some students are shy or reserved and feel awkward when working with others.

\section{Reading Comprehension}

According to Hornby (1998) states that reading comprehension is not just reading with a loudly voice but reading is established to understand the meaning of words, sentences, and paragraph senses relationship among the ideas. If the students just read and cannot understand the content of the text, it means that they fail in comprehension. Next, Smith and Johnson, (1978: 56) states that reading comprehension means the understanding, evaluating, utilizing of the information and gaining through an interaction between reader and author. Reading comprehension is such as a kind of dialogue between an author and reader in which the written language becomes the medium. Addition, Wainwright (2007:37) explains reading comprehension is the act of understanding what you are reading. While the definition can be simply stated the act is not simple to teach, learn or practice. Reading comprehension is an intentional, active, interactive process that occurs before, during and after a person reads a particular piece of writing.

Based on some opinions above, we can conclude that reading comprehension is about understanding written text and as an ability or capacity for comprehending reading material to gain some information from the reading text. It is a complex activity that involves both perception and thought. Reading consists of two related process, word recognition and comprehension. Word recognition refers to the process of perceiving how written symbol correspondent to one spoken language 
Indah Fadhilah Rahman, The Implementation of Collaborative Strategy Reading (CSR) ...

and comprehension is the process of making sense of words, sentences and connected text.

\section{The Students' Attitudes}

Anastasi, A., \& Urbina, S (1997:405) clarify that an attitude is often defined as a tendency to react favorably or unfavorably toward a designed class of stimuli such as a national or ethnic, group, a custom, or an institution when so defined; attitudes cannot be directly observed but must be inferred from overt behavior, both verbal and nonverbal. Allport (in Martin B. L., \& Briggs, L. J, 1986:100) suppose that an attitude is a mental and neutral state of readiness, organized through experience, exerting a directive or dynamic influence upon the individual's response to all objects and situation with which it is related.

\section{Social Constructivist Theory (SCT)}

Recently, English language teaching, in many countries including Indonesia, is emphasized on Communicative Language Teaching (CLT) approach (Mackay, 2002: 106; Albert and Kormos, 2004: 284). CLT Movement has bought sosial interaction to an impotant thing that, as a core of communication which plays a significat role of EFL Learning. CLT is an umbrella for collaborative learning. According to Roger et al (1992: 8) in Huda (2011), cooperative learning is a group learning activity organized in such as way that learning is based on the socially structured change of information between learners in group in which each learner is held accountable for his or her own learning and motivated to increase the learning of other. CLT movement has recorded four theories that strongly influence the ideas of SCT: a) Vygotsky's Social Learning Theory, b) Brunner Learning Theory, c) Bandura's Social Cognitive Theory, and d) Piaget's Genetic Epistemonology Theory.

\section{RESEARCH METHODOLOGY}

This research applied the experimental research by using two groups' pre test and post test. The experimental research is only method of research that can truly test hypotheses concerning cause and effect relationships. The researcher used two classes. The experimental research involved one experimental group and one control group.

Design of the Research

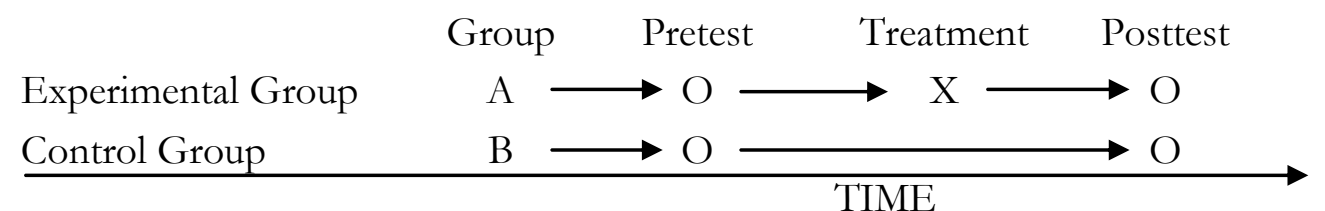

James. H Mc Millan \& Sally S (1993: 310) 


\section{The Procedures of CSR}

Each learning strategy has a certain steps or procedures. According to Janette K, Klingner and Sharon Vaughn, (1996) especially, propose four steps or procedures in using CSR to teach any subject, including reading comprehension. The appropriate procedures of CSR in teaching reading comprehension encompassed the following:

\section{a. Preview:}

1) Brainstorming the text by seeing the pictures and the title to find the topic;

2) Discussing and sharing the ideas to determine the best topic;

3) Predicting the topic that will be learnt

4) Sharing to find the best prediction.

\section{b. Click and clunk}

1) Identifying the difficult or unknown words in the text.

2) Guiding the students to use context clues strategy to overcome their clunks.

3) Sharing in group to determine the best meaning of the words.

\section{c. Get the gist}

1) Identifying the text and guiding them to find the important idea (the main idea) of each paragraph of the text by using paragraph shrinking;

2) Sharing in group to find the best main idea of each paragraph.

\section{d. Wrap-up}

1) Guiding the students to review the whole text by summarizing the important ideas of the text/the story;

2) Sharing to find the best review; and

3) Answering the comprehension questions in group related to the text to check the understanding the text.

\section{D.HYPOTHESES}

This study has two hypotheses in relation to the research questions

1. There is a significant difference between students' proficiency in reading comprehension of experimental and control group before and after treatment.

2. There is a significant correlation between the students proficiency in reading comprehension and the student' attitude in learning by using CSR.

\section{a. Location of the Research}

The study was conducted at Madrasah Aliyah Negeri MAN 1 Makassar in two months started in March 2012 till June 2012. 
Indah Fadhilah Rahman, The Implementation of Collaborative Strategy Reading (CSR) ...

\section{b. Sample and Population}

The target population was 123 students of the second year students at Madrasah Aliyah Negeri MAN 1 Makassar, in academic year 2011/2012. The samples were 40 students taken from $20 \%$ of the total population. The samples were selected through purposive random sampling adopted from Gay (1981).

\section{c. Data Collection}

In collecting data, there are two instruments: reading test and questionnaire. The researcher measured the students' reading comprehension in the two groups before and after study by reading pre-test and post-test and conducted questionnaire to know the students' attitudes towards the use of collaborative strategy reading (CSR).

\section{d. Data Analysis}

The students' proficiency in reading comprehension were analyzed by the criterion-reference system in ESL composition profile which is described by Wayan N \& P.P.N Sumartama (1986). The data then were analyzed and interpreted by means of SPSS 14.0 and the statictical formula by Gay (1990). The students' atitudes data were analyzed by using likert's scale (Aiken, 1998).

\section{E. RESEARCH RESULTS}

\section{The students' attitude toward use of CSR}

The finding of this research shows that students' proficiency has positive significant correlation with students' attitudes. The result of the students' attitudes can be divided into three categories: very high score, high score, and enough score. There are $45 \%$ (9) of the students get very high score, $50 \%$ (10) of the students get high score, 5\% (1) of the student gets enough score with the mean score is 60.85 and the position is in high level. It means that the implementation of collaborative strategy reading classroom is good because 95\% (19) of the total students' attitudes get high to very high score and only 5\% (1) of the student gets enough score. The researcher found that the result of the significance correlation between the students' reading proficiency and attitude r-test was 0.607 and t-table is 0.423 at 0.05 level of significant at 19 degrees of freedom (T-observed $>$ T-table, $\alpha=0.05)$. Sig. (2-tailed) is the r-test value is higher than t-table $(0.0607>0.423)$. It means that there is significant corellation between students' proficiency and attitudes

\section{The students' reading comprehension achievement}

The data collected through pre-test and post-test shows that the students' proficiency in reading comprehension of the two groups improved significantly. The 
pre-test mean score of experimental group is lower than the control group $=$ $40.80>42.00$. The students' previous performance in experimental class is different from the students in control group. The researcher found that the t-observed value is lower than t-table, where t-observed is 0.333 and t-table is 2,024 at 0.05 level of significant at 38 degrees of freedom (T-observe $<$ T-table, $\alpha=0.05)$. Sig. (2-tailed) is $0.333<2.024$.

There is a significant improvement in experimental group post-test. The mean score in pre-test enhance 40.80 to 78.40 in post-test. The mean difference in paired sample test shows the number of $37.60(78.40-40.80)$ and the standard deviation is 7.272. The researcher found that the t-observed value is higher than t-table, where $t-$ observed is 23.123and t-table is 2.093 at 0.05 level of significant at 19 degrees of freedom (T-observed $>$ T- table, $\alpha=0.05$ ). Sig. (2-tailed) is 23.123>2.093.

In control group's post-test, there is also improvement. However the improvement is not as large as experimental group. The mean score of control group in pre-test enhance from 42.00 to 51.20. The mean difference in paired sample test shows 9.20 (51.20-42.00) with the standard deviation 6.237. The researcher found that the t-observed is higher than t-table, where t-observed is 6.280 and t-table is 2.093 at 0.05 level of significant at 19 degrees of freedom (T-observed $>$ T-table, $\alpha=$ 0, 05) Sig. (2-tailed) is $6.237>2.093$.

The outcome of the students' improvement of experimental group and control group display a significant difference. The researcher found that the t-observed is higher than t-table, where t-observed is 8.592 and t-table is 2.024 at 0.05 level of significant at 38 degrees of freedom (T-observed $>$ T-table, $\alpha=0.05)$. Sig. (2-tailed) is $8.592>2.024$.

\section{F. DISCUSSIONS}

The result from the pre-test and post-test demonstrated a significant improvement in the quality of the students' reading comprehension in the experimental group while the quality of students' reading comprehension in control condition was increased. This implies that the students in both groups gained in the reading proficiency, but those in the experimental condition gained more. It is indicated that CSR with the teacher's support improved the students' proficiency in reading comprehension significantly.

The result of the study (the students' reading proficiency was significantly improved after the treatment) is same from that previous research by Noheriandy (2010), Hadi (2011) and Fitriana (2010). These researchers found there was significant difference in the quality of the students' reading comprehension before 
Indah Fadhilah Rahman, The Implementation of Collaborative Strategy Reading (CSR) ...

and after research. However, the present study demonstrated a significant improvement in the quality of the students' proficiency in reading comprehension. One reason for the improvement in the quality of the students' reading comprehension could be explained in terms of the preview, clik and clunk, get the gish and wrap up. Each student in experimental group did the four of CSR techniques. Therefore, the students learning process can be very effective, constructive, and valuable, which might helping by other and sharing ideas, can improve the quality of their comprehen in reading comprehension. Another reason that contributes to the development of the students' reading proficiency could relate to brainstorming and discussion that followed. (Vigotsky, 1896 in Pritchart and Woollard, 2010) say that the existing prior knowledge of the child will develop by interaction social. It is mean that in a learning process needs interaction social. Learning process can be categorized suscess if there interaction by means stimulus and response between students and students, teacher and students. These two aspests are very inpotant thing in learning because it will created the situation and condition which are condusive and interesting envoroment: sharing ideas, peer teaching to solving the problem and discussion. The researcher also believes that it is the share ideas, helping by others and discussions that the students could help them avoid confusion and uncertainty. Finally, it could be the case that the students' selfesteem might play role in the improvement of the students'reading proficiency.

The improvement of students' proficiency in reading has significant correlation with the students' attitudes. The finding indicates that the highest rank of the mean score is $42 \%$ of agree students. The second is $36 \%$ of the students choose strongly agree. The third, $14.5 \%$ of students choose undecided, $6.5 \%$ choose disagree and only $1 \%$ of student chooses strongly disagree answer to the statements. It can be concluded that $78 \%$ of the students choose "agree" and "strongly agree" to the statements. There are $7.5 \%$ of students choose "disagree" and "strongly disagree" and $14.5 \%$ students choose "undecided" or "neutral". The finding indicates that the CSR is responded positively by the students in experimental group. It means that this strategy can improve the students' reading proficiency and it can be applied in teaching reading comprehension.

\section{G. CONCLUSION AND SUGGESTION}

It is concluded that collaborative strategy reading (CSR) has a significant effect on students' reading comprehension. The implementation of CSR is responded positively by the students and the application is preferable. In this case, the researcher would like to suggest to English teacher at Madrasah Aliyah Negeri 
MAN 1 Makassar to think about the CSR in teaching reading comprehension. Also, teaching reading comprehension using conventional method should not be considered as useless. Even though it is an old-fashioned teaching technique, but after some serious treatment, the technique still can improve students' reading proficiency. Of course, more various updated teaching techniques must be compared and CSR is one of reasonable choice.

\section{BIBLIOGRAPHY}

Aiken, L. S. 1982. Psychological Testing and Assessment. $4^{\text {th }}$ ed. Boston: Allyn and Bacon.

Bandura, Albert. (2001). Social Cognitive Theory: An Agentic Perspective. Annual Reviews (Online), downloaded on 17 March 2012. Available from: http://www.AnnuaIReviews.org/

Brown, H. Douglas. (2001). Teaching by principles. An Interactive Approach to Language Pedagogy. Second Edition. New York: Addison Wesley Longman Inc.

Dryden, G., \& Vos, Jeannette. (1999). Learning Revolution: To Change the Way the World Learns. Auckland, New Zealand: The Learning Webb.

Gay, L. R. (1990). Educational Research: Competencies for Analysis and Application, $3^{\text {rd }}$ ed. Singapore: Macmillan Publishing Company.

Hadi, D.J. (2011). Improving Students' Reading Comprehension Using Cooperative Integrated and Coposition (circ) in the X grade immersion students of SMA Negeri 2 Karanganger. Thesis (Online): Teacher Training and Education Faculty, Sebelas Maret University: downloded on 28 May 2012. Available from: bttp:// www.englishfkipuns.ac.id/index.php/ research/ 7 researchmahasiswa/119/improvi ng-students-reading-comprehension-using-cooperative-integrated-reading-and-compositioncirc. .

Janned K. Klingner \& Sharon Vaughn.(1998). Using Collaborative Strategy reading: The council for exeptional children. Teaching Exceptional Children Journal (Online): Juli-August pp. 32-36, downloded on 25 Jan 2011. Available from: Http:/ / Nepc.Colorado.Edu/Files/VaughnerKlingner Teachingreadingcomprehensionth roughcsr.Pdf.

Janned K. Klingner \& Sharon Vaughn. (1999). Teaching Reading Comprehension through Collaborative Strategy Reading. Interversion and School Clinic Journal (Online) Vol.34 no.5, downloded on 16 June 2011. Available from: http://nepc.colorado.edu/files/Vaughn\&Klingner TeachingReadingCompre hensionthroughCSR.pdf.

Johnson, D.W., \& Johnson, R.T. (1987). Learning Together and Alone: Cooperative, Competitive and Individualistic Learning. $3^{\text {rd }}$ ed. Boston in Allyn and Bacon. 
Indah Fadhilah Rahman, The Implementation of Collaborative Strategy Reading (CSR) ...

Nohenriady (2011). Using Collaborative Strategic Reading (CSR) to Improve the Eighth Graders' Reading Comprehension at MTsN Sungai Pandan South Kalimantan. Thesis (Online), downloded on 16 June 2012. Available from http://karya ilmiah.um.ac.id/index.php/disertasi/article/view/13976.

Palincsar, A. S., \& Brown, A. L., \& Campione, J. (1989). Structured dialogues among communities of first-grade learners. Paper presented at the annual meeting of the american educational research association, san francisco, california in elizabeth foster and becky rotoloni: The University Of Georgia. Article (Online), downloded on 16 June 2012. Available from: http://projects.coe.uga.edu/epltt/index.php?title=Reciprocal Teachig.

Pardo, Laura S. (2004). What Every Teacher Needs to Know About Comprehension: In the Reading Teacher. pp. 272-281

Pritchard, Alan and Woollard, John. (2010). Psychology for the Classroom: Constructivism and Social Learning. Taylor and Francis e-Library (Online). Available from: http://www.eBookstore.tandf.co.uk/

Suryabrata, Sumadi. (2011). Psikologi Pendidikan. Jakarta: PT. RajaGrafindo Persada.

Tobias, Sigmund and Duffy, Thomas M. (2009). Constructivist Instruction: Success or Failure?. Taylor and Francis e-Library (Online), downloaded on 20 April 2010. Available from: http://www.eBookstore.tandf.co.uk/ 